\title{
JM
}

Volume 6 No. 2 (Oktober 2018)

(C) The Author(s)

\section{EFEKTIVITAS HIPNOSIS PADA PENATALAKSANAAN CEMAS DAN NYERI PERSALINAN (STUDI LITERATUR)}

\author{
EFFECTIVITY OF HYPNOSIS ON ANXIETY AND LABOR PAIN (LITERATURE \\ REVIEW)
}

\author{
DIYAH TEPI RAHMAWATI \\ LECTURER OF MIDWIFERY DEPARTEMEN DEHASEN UNIVERSITY \\ E-mail :_cecoatepay@gmail.com
}

\begin{abstract}
ABSTRAK
Pendahuluan. Selama proses persalinan, terjadi penurunan kepala janin kedalam rongga panggul ibu yang menekan syaraf pudendal sehingga mencetuskan sensasi nyeri yang dirasakan oleh ibu. Kondisi ini memengaruhi fisik dan psikologis ibu. Pengalaman perempuan pada nyeri persalinan beragam dan rumit tetapi intensitas nyeri dapat diperburuk oleh rasa takut, ketegangan dan kecemasan. Teknik seperti hipnosis telah disarankan sebagai cara untuk membantu mengatasi ketakutan dan kecemasan. Tujuan dari telaah jurnal ini adalah melihat keefektivan hipnosis pada penatalaksanaan cemas dan nyeri persalinan. Metode. Metode yang digunakan adalah tinjauan literatur, sumber meliputi studi pencarian sistematis database terkomputerisasi (Pubmed, The Cochrain Collaboration, Elsevier, Google Scholar). Jurnal yang digunakan berjumlah 11 Jurnal. Diskusi. Hipnosis merupakan sugesti postif terfokus yang menguntungkan untuk ibu pada persalinan dan kelahiran. Kelancaran proses persalinan salah satunya dipengaruhi oleh ketenangan dan kenyamanan ibu, keadaan santai akan membuat kontraksi uterus tetap terjaga. Ibu bersalin yang dihipnosis maka kecemasan dan nyeri persalinan dapat dikelola, sehingga berdampak pada kemajuan persalinan. Kesimpulan. Hipnosis dapat membantu ibu meringankan kecemasan dan nyeri dalam persalinan. Dengan hipnosis ibu bersalin dapat lebih percaya diri, tenang dan nyaman serta dapat menjalin hubungan batin yang erat dengan janinnya. Untuk itu Hipnosis dapat digunakan sebagai alternatif dan salah satu metode non farmakologi yang bermanfaat. Hipnosis terbukti efektif pada penatalaksanaan cemas dan nyeri persalinan.
\end{abstract}

\section{Kata kunci : Hypnosis, Cemas, Nyeri Persalinan}

\begin{abstract}
Background. During labor, there is a decrease of the fetal head into the mother's pelvic cavity that suppresses the pudendal nerve resulting in the sensation of pain felt by the mother. This condition affects the physical and psychological mother. Women's experience of labor pain is diverse and complicated but the intensity of pain can be exacerbated by fear, tension and anxiety. Techniques such as hypnosis have been suggested as a way to help overcome fear and anxiety. The purpose of this study is to look at the effectiveness of hypnosis in the management of anxiety and labor pain. Method. The method used is a literature review, the sources include a systematic search study of a computerized database (Pubmed, The Cochrain Collaboration,
\end{abstract}


Elsevier, Google Scholar). The journal used amounted to 11 Journals. Discussion. Hypnosis is a focused positive suggestion for the mother in labor and birth. The smoothness of the birth process is one of them influenced by the peace and comfort of the mother, relaxed circumstances will make the uterine contractions are maintained. Maternity mothers who are hypnotized then anxiety and labor pain can be managed, thereby affecting the progress of labor. Conclusion. Hypnosis can help mothers relieve anxiety and pain in labor. With maternity hypnosis can be more confident, calm and comfortable and can establish a close inner relationship with the fetus. For that Hypnosis can be used as an alternative and one useful nonpharmacological method. Hypnosis has been shown to be effective in the management of anxiety and labor pain.

\section{Keywords: Hypnosis, Anxiety, Labor Pain}

\section{PENDAHULUAN}

Persalinan dan kelahiran merupakan proses fisiologis yang harus dialami oleh seorang ibu. Selama proses persalinan, terjadi penurunan kepala janin kedalam rongga panggul ibu yang menekan syaraf pudendal sehingga mencetuskan sensasi nyeri yang dirasakan oleh ibu. Selain itu nyeri persalinan juga disebabkan oleh kontraksi yang berlangsung secara reguler dengan intensitas yang semakin lama semakin kuat dan semakin sering. Kondisi ini memengaruhi fisik dan psikologis ibu.

Pada saat persalinan ibu merasa sangat terpengaruh oleh lingkungan, penolong melakukan asuhan rutin secara berkala, banyak intervensi, petugas kesehatan yang tidak dikenal, berkurangnya rasa nyaman dan kondisi lain yang mengakibatkan munculnya pengalaman kurang baik, kondisi ini mempunyai pengaruh kepada kemajuan persalinan dan perasaan mampu serta percaya diri pada ibu.

Pengalaman perempuan menghadapi nyeri dalam persalinan beragam dan rumit tetapi intensitas nyeri dapat diperburuk oleh rasa takut, ketegangan dan kecemasan. Teknik seperti hipnosis telah diusulkan sebagai cara untuk membantu mengatasi ketakutan ini dan kecemasan. Hipnosis adalah keadaan yang berubah dari kesadaran yang melibatkan, sebagian fokus perhatian untuk mengurangi kesadaran eksternal lingkungan. Peningkatan respon individu dalam hipnotis untuk komunikasi, yang dikenal sebagai saran, dapat berguna memfasilitasi perubahan persepsi dan perilaku. Wanita dapat dipandu ke dalam hipnosis oleh seorang praktisi selama persalinan atau individu dapat belajar hipnosis mandiri selama kehamilan, untuk penggunaan selanjutnya selama persalinan. Pelatihan antenatal ini kadang-kadang dilengkapi dengan audio rekaman sugesti hipnosis. ${ }^{1}$

Untuk melahirkan, hipnosis sering digunakan untuk memusatkan perhatian pada perasaan nyaman atau mati rasa serta meningkatkan perasaan perempuan dari relaksasi dan rasa aman.

Dari penelitian Fitria Hayu Palupi Tahun 2012 tingkat kecemasan dalam menghadapi persalinan kala I juga terjadi pada ibu primigravida dan multigravida meskipun telah memiliki pengalaman persalinan. ${ }^{2}$.

Selain itu, perbedaan antara harapan wanita dan kenyataan yang ada pada saat persalinan juga akan berpengaruh pada persepsi dan perasaan. Hal ini mungkin akan menyebabkan perasaan seperti kecewa, perasaan bersalah dan kegagalan. Sejak wanita memahami pengalaman persalinan yang memerlukan istirahat, memungkinkan mereka untuk membuat informed choice dan untuk mengontrol perasaan selama persalinan, merupakan hal yang penting sehingga dapat mengurangi dampak cemas dan nyeri.

Hipnosis dapat bermanfaat sebagai metode manajemen nyeri persalinan, tetapi tercatat bahwa hanya sejumlah kecil perempuan telah belajar (Smith 2006). ${ }^{3}$

Perlu adanya penatalaksanaan yang 
tidak hanya berfokus pada perubahan fisiologis khususnya pada ibu bersalin di fase laten kala I persalinan, tetapi penatalaksanaan dalam hal perubahan psikologi pun sangat diperlukan. Berdasarkan kebutuhan tersebut, perlu dibahas tentang efektivitas hipnosis pada penatalaksanaan cemas dan nyeri persalinan.

\section{METODE PENELITIAN}

Studi ini merupakan sebuah tinjauan literatur (Literatur Review) yang menggali lebih banyak informasi mengenai efektivitas hipnosis pada managemen cemas dan nyeri persalinan. Sumber untuk melakukan tinjauan literatur ini meliputi studi pencarian sistematis database terkomputerisasi (Pubmed, The Cochrain Collaboration, Elsevier, Google Scholar). Dalam kesempatan ini jurnal penelitian yang digunakan sebagai referensi berjumlah 11 Jurnal. Penulisan artikel ilmiah ini menggunakan penulisan daftar pustaka vancouver.

\section{HASIL PENELITIAN}

Kata hipnosis berasal dari bahasa Yunani 'hypnos' yang berarti 'tidur'. Bahkan, tidak tidur tapi keadaan terfokus konsentrasi di mana pasien relatif tidak menyadari, tapi tidak benar-benar buta dengan lingkungannya. Selama hipnosis, sugesti dapat dibuat, dengan fokus pada berkurangnya rasa nyeri, rasa takut dan kecemasan. ${ }^{3,4}$

Ibu bersalin dipersiapkan dengan pengalaman hipnotis awal yang meliputi tiga langkah yaitu penyerapan kata-kata atau gambar yang disajikan oleh terapis, disosiasi, suspensi penilaian kritis, dan responsif. Beberapa komparatif studi telah mengevaluasi efisiensi hipnosis. ${ }^{3}$

Hipnosis dapat digunakan untuk mengurangi rasa takut, ketegangan dan nyeri selama persalinan dan untuk meningkatkan ambang nyeri. Hal ini tentunya akan mengurangi kebutuhan akan analgesia kimia. pasien memiliki kontrol yang lebih baik terhadap kontraksi yang menyakitkan. Oleh karena itu, hipnosis dianggap bermanfaat pada kehamilan selama persalinan dan kelahiran. ${ }^{1,3,5}$

Dalam kaitan manajemen nyeri persalinan, hipnosis sering dianggap bersama metode non-farmakologis lainnya sebagai berfokus pada aspek afektif dari pengalaman nyeri, seperti mengurangi kecemasan, ketakutan, ketegangan otot serta meningkatkan suasana hati dan meningkatkan rasa kontrol ibu (Simkin 2004).

Manajemen nyeri salah satu daerah di mana penerapan hipnosis menunjukkan bukti empiris berlimpah sebagai nya keberhasilan adalah dalam pengelolaan baik nyeri kronis dan akut (Lynn et al, 2000, Montgomery, DuHammel \& Redd, 2000). Kedua pengakuan oleh The National Institut Teknologi Kesehatan Panel Laporan (1996) dan meta-analisis review oleh Montgomery et al. (2000) tentang kemanjuran hipnosis manajemen nyeri mendukung pertimbangannya sebagai berkhasiat, mapan, dan empiris divalidasi pengobatan. dalam Montgomery et al. (2000) review, ditemukan bahwa hipnosis dapat meringankan berbagai jenis nyeri pada $75 \%$ dari penduduk. $^{6}$

Pada studi literatur yang dilakukan Madden K, et al Tahun 2012, dalam tujuh percobaan yang dilakukan secara acak 1.213 perempuan untuk hipnosis atau untuk mengendalikan kelompok yang menerima; persiapan melahirkan standar ,perawatan biasa , kaset relaksasi gabungan dengan praktek relaksasi dalam kelas antenatal ,konseling atau psikoterapi suportif mendukung. Tidak ada perbedaan yang signifikan antara perempuan dalam kelompok hipnosis dan mereka yang berada di kelompok kontrol dalam hal penggunaan tambahan obat-obatan untuk manajemen nyeri , yang jumlah persalinan normal atau kepuasan perempuan dengan metode penghilang rasa sakit.

Hasil : Satu uji dilaporkan bahwa hipnosis mengurangi intensitas nyeri, memperpendek waktu persalinan dan mengurangi jumlah perempuan yang tinggal 
di rumah sakit selama lebih dari dua hari setelah bayi mereka lahir dibandingkan dengan wanita yang menerima pelatihan relaksasi atau konseling suportif. Bukti lebih lanjut diperlukan untuk mengkonfirmasi temuan ini . Dalam enam percobaan perempuan dilatih dalam hipnosis mandiri selama kehamilan untuk digunakan selama persalinan. $^{1}$

Berdasarkan beberapa studi jurnal diatas dapat disimpulkan hipnosis merupakan pengalihan rasa nyeri dengan memberikan sugesti postif terfokus pada ibu yang dapat memberikan keuntungan pada kehamilan, selama persalinan dan kelahiran. Kelancaran proses persalinan salah satunya dipengaruhi oleh ketenangan dan kenyamanan ibu dimana jika ibu dalam keadaan tenang tentunya akan membuat kontraksi uterus tetap terjaga. Dengan hipnosis pada ibu bersalin penanganan cemas dan nyeri dapat dikelola sehingga berdampak pada kemajuan persalinan.

\section{PEMBAHASAN}

Hasil penelitian menjelaskan adanya pengaruh dari pemberian teknik hypnobirthing terhadap penurunan tingkat kecemasan ibu primigravida dalam menghadapi proses persalinan serta ketakutan paling tinggi dalam tahap awal persalinan aktif terjadi pada ibu primipara. ${ }^{2,7}$

Menurut hemat penulis, menurunkan rasa cemas atau takut, pada persalinan pada gilirannya dapat mengurangi kebutuhan nyeri ibu. Dalam hal ini hipnosis diperlukan untuk ibu bersalinan agar lebih tenang, santai, percaya diri dan nyaman.

Landolt dan Penggilin Tahun 2011 mengemukakan hipnosis oleh praktisi dan hipnosis mandiri secara konsisten terbukti lebih efektif daripada perawatan medis standar, konseling suportif, dan kelas pendidikan persiapan melahirkan dalam mengurangi rasa sakit. lainnya manfaat termasuk skor Apgar bayi yang lebih baik dan lebih pendek ${ }^{813}$

Saat ini bukti penelitian masih terbatas tentang kepuasan perempuan dengan pengalaman persalinan mereka saat menggunakan hipnosis mandiri; Namun, hasil menunjukkan bahwa dengan hipnosis oleh praktisi dan hipnosis mandiri, perempuan akan merasa lebih santai atau nyaman selama persalinan dan menjadi lebih mungkin untuk menikmati pengalamannya. Ibu yang menggunakan hipnosis lebih mungkin untuk melahirkan tanpa nyeri dan tanpa penggunaan obat farmakologis. Ada bukti peningkatan persalinan spontan dan hasil yang lebih baik untuk bayi, tapi penelitian berkualitas tinggi diperlukan untuk menunjukkan jenis-jenis intervensi hipnosis yang paling efektif dan memenuhi kebutuhan perempuan. Landolt dan Penggilin menyarankan penggunaan 'perawatan mandiri' untuk meningkatkan keberhasilan yang tetap, praktek hipnosis berkelanjutan dan evaluasi terus menerus untuk memungkinkan penelitian lanjutan.

Hipnosis adalah prosedur oleh praktisi atau peneliti untuk merubah sensasi, persepsi, pikiran, atau perilaku klien, pasien, atau subjek. ${ }^{8,9}$

Hipnosis mungkin bermanfaat untuk pengelolaan nyeri selama persalinan; Namun, jumlah perempuan yang diteliti masih sedikit. Beberapa terapi lainnya telah mengalami penelitian lebih lanjut ( Smith, 2010). ${ }^{10,11}$

Dari studi Pebrayati, 2013 di wilayah III Cirebon menunjukkan median intensitas nyeri persalinan kala I fase laten pada kelompok hypnobirthing adalah 4,5 dan pada kelompok tanpa hypnobirthing adalah 6, dengan analisis Mann Whitney didapat nilai $p=0,050$. Intensitas median nyeri persalinan kala I fase aktif pada kelompok hypnobirthing adalah 5 dan pada kelompok tanpa hypnobirthing adalah 9, nilai $\mathrm{p}=0,01$. Selisih perubahan intensitas nyeri menggunakan uji satu arah menunjukan penggunaan hypnobirthing secara signifikan dapat menurunkan intensitas nyeri persalinan, nilai $p=0,034$. Dengan demikian hypnosis berperan pada penurunan nyeri persalinan Kala I. ${ }^{12}$

Dari telaah beberapa jurnal diatas penulis melihat bahwa pengaruh hipnosis 
pada ibu bersalin efektif pada penatalaksanaan cemas dan nyeri dimana ibu akan merasa santai dan lebih nyaman dalam menghadapi atau selama proses persalinannya meskipun masih memerlukan studi lebih lanjut sehingga hasilnya lebih valid.

\section{KESIMPULAN}

Hipnosis merupakan sugesti positif terfokus yang dapat dilakukan sendiri maupun dengan pendamping. Teknik hipnosis sangat bermanfaat untuk ibu dan dapat dipersiapkan sejak kehamilan serta bermanfaat untuk proses persalinan dan kelahiran.

Hipnosis juga dapat membantu ibu meringankan kecemasan dan nyeri dalam persalinan. Hipnosis oleh praktisi dan hipnosis mandiri dapat membuat ibu lebih menikmati persalinannya. Hipnosis dapat diaplikasikan dalam proses persalinan untuk mengatasi rasa nyeri saat kontraksi rahim dan persalinan. Dengan ibu lebih tenang dapat mempengaruhi kemajuan persalinan.

Hipnosis dapat bermanfaat untuk ibu dan janinnya. Ibu bersalin dengan hipnosis dapat lebih percaya diri, tenang dan nyaman serta dapat menjalin hubungan batin yang erat dengan janinnya. Saat persalinan, keduanya bisa saling "berjanji" untuk bersama-sama melewatinya.

\section{SARAN}

Untuk itu hipnosis dapat digunakan sebagai alternatif dan salah satu metode non farmakologis yang bermanfaat saat persalinan dan kelahiran. Hipnosis terbukti efektif pada penalataksanaan cemas dan nyeri persalinan. Perlu dilakukan penelitian serta review lebih lanjut dari studi studi lainnya untuk hasil yang lebih valid.

\section{DAFTAR PUSTAKA}

Madden ea. Hypnosis for pain management during labour and childbirth. The Cochrane Collaboration. 2012(11).
Palupi FH. Perbedaan tingkat kecemasan ibu primigravida dengan multigravida dalam menghadapi proses persalinan kala I di rumah bersalin Ngudi Saras Jateng Karanganyar. Maternal. 2012;8.

Semple Amy MN. Self-hypnosis for labour and birth. NCT's journal on preparing parent $\mathrm{s}$ for bi $\mathrm{r}$ th and ear ly parenthood. 2011;1(1):5.

Sado $\mathrm{M}$ ea. Hypnosis during pregnancy, childbirth, and the postnatal period for preventing postnatal depression. The Cochrane Collaboration. 2012(6).

Marc I ea. Mind-body interventions during pregnancy for preventing or treating women's anxiety. The Cochrane Collaboration. 2011(11).

Barragán Loayza IM ea. Biofeedback for pain management during labour. The Cochrane Collaboration. 2011(6).

Agustina R. Perbedaan Tingkat Kecemasan Ibu Primigravida Terhadap Proses Persalinan Sebelum Dan Sesudah Dilakukan Teknik Hypnobirthing Di Pro-V Clinic Jakarta. Jakarta: Poltekkes Kemenkes Jakarta III Kemenkes RI; 2014.

Landolt Alison S. MLS. The efficacy of hypnosis as an intervention for labor and delivery pain: A comprehensive methodological review. Clinical Psychology Review. 2011;31:102231.

M. Elena Mendoza AC. Efficacy of clinical hypnosis : A summary of its empirical evidence. Papeles del Psicologo. 2009;30(2):98-116.

Smith CA ea. Complementary and alternative therapies for pain management in labour (Review). The Cochrane Collaboration. 2010(9).

Tournaire M YA. Complementary and Alternative Approaches to Pain Relief During Labor. eCAM. 2007;4(4):10.

Pebriyati, Elit, ea. Pengaruh Hypnobirthing pada penurunan 
intensitas nyeri persalinan kala I. Buletin Poltekkes Tasikmalaya. 2013

Nasyiba, Wielda. Gambaran pengalaman bidan dalam menerapkan teknik hypnobirthing. Ema Conference.

2011 